\title{
WHY THE 'ONE-SIZE-FITS-ALL' SUBSIDY STRUCTURE OF TABUNG HAJI NO LONGER WORKS AND HOW TO MOVE FORWARD
}

\author{
Nur Hasnida Abdul Rahman* \\ Mohd Zaidi Md Zabri**
}

\begin{abstract}
The original, novel idea behind Tabung Haji's establishment was to help Malaysian Muslims save for hajj. However, throughout the years, the subsidy amount for hajj pilgrims has proven to be ever-increasing. As a case in point, for the 2020 hajj season, a first-time hajj pilgrim needs only pay RM9980 out of RM22,900 of the original costs. Stated differently, Tabung Haji subsidises more than half ( 56.42 per cent) of the total cost. As with any subsidy, the main question is, where do we find the money? For instance, the governments of Muslim majority nations such as Pakistan and Indonesia used to directly subsidise their hajj pilgrims but have recently stopped doing so. Moreover, Tabung Haji is a business entity, which understandably needs to generate profit that will then be used to subsidise hajj pilgrims. Consequently, this paper aims to examine the (un)sustainability of the existing subsidy structure and suggest a way forward. Due to its politically sensitive nature, instead of eliminating the subsidy, the authors used data from the Household and Basic Amenities Survey 2019 to mathematically simulate a regressive subsidy structure for firsttime hajj pilgrims.
\end{abstract}

Keywords: Hajj, Tabung Haji, subsidy, financial literacy.

\section{Introduction: Tabung Haji's Pain Points}

Lembaga Tabung Haji (TH) was established in 1963 as a specially mandated Islamic financial institution dedicated to managing the hajj (pilgrimage) ${ }^{1}$ fund for Malaysian Muslims. Since its inception, TH has gained a high level of confidence, as evidenced by its substantial capital, high deposit growth, and profit level every year. TH has consistently been praised by the Kingdom of Saudi Arabia as one of the world's best hajj management institutions. ${ }^{2}$ As a result, TH has been a popular savings instrument among Malaysian Muslims, primarily due to the high amount of its yearly hibah (gift) and subsidy for hajj costs. 
Malaysia's $14^{\text {th }}$ General Election (GE14), held on 9 May 2018, saw an historic change in government for the first time since Malaya's independence in $1957 .{ }^{3}$ As with many government-linked companies (GLCs) in Malaysia, TH had a history of political appointees among its top management and, consequently, after GE14 there were significant changes in the board of directors and management team. Part of a cleaning-up process, the new appointees included business professionals with no direct political ties to the ruling government. Subsequently, police reports were lodged against TH's previous management team, accusing them of mismanaging its financial records for the financial year 2017. The National Audit Department audited TH's financial statements for 2017, while Pricewaterhouse Coopers (PWC) was roped in as an independent reviewer. Between November 2018 and March 2019, it was discovered that TH's financial statements for 2017 had failed to disclose its actual financial position. The main issues included the non-disclosure of impaired assets and overstatement of asset amounts and net profit position.

Impairment is an accounting principle describing a permanent reduction in the value of a company's assets. According to the audited report, TH failed to impair the significant decline in the value of its investments. Therefore, TH's financial statements for the financial year ending 2017 were overstated: the recorded profit of RM3.41 billion omitted an impairment loss on available-for-sale (AFS) equity investments of RM4.26 billion, on AFS debt security instruments of RM7 million, and other adjustments of RM4.85 billion. With the impaired amounts taken into consideration, the fund should have made a RM1.43 billion loss in 2017. This has subsequently impacted the retained earnings position of RM162 million, in which TH should have recorded an accumulated loss of RM4.68 billion as of 31 December 2017. Moreover, it was also found that TH's asset impairment policies were changed almost yearly, especially during FYE 2017, whereby the policy was modified twice from its initial 70 per cent to 85 per cent and 90 per cent respectively. According to PWC, these policy changes strategically deferred impairment losses, which enabled TH to announce a certain level of distribution to depositors in 2017, namely hibah of 4.5 per cent and hajj hibah of 1.75 per cent. ${ }^{4}$ Stated differently, the depositors' hibah was paid based on overstated figures and in direct contravention of the Tabung Haji Act 1995. According to that Act's Section 22, hibah can only be declared and subsequently paid if TH's assets are more than its liabilities. This subsequently raised concerns over the source and legality of the dividend payment. Another series of independent audits were performed, which revealed an alarming financial position that subsequently put $\mathrm{TH}$ under a restructuring exercise. 


\section{Remedies: The Restructuring of TH}

The financial problems faced by TH give rise to several issues. Even though the institution is meant for hajj fund savings, it is not obligated to pay a high return to depositors. Nevertheless, TH is traditionally known for its high return rate in hibah and hajj subsidies. Thus, the declaration of yearly hibah is very much anticipated by depositors. Given TH's current financial situation, which is still in its recovery stage, it is challenging for $\mathrm{TH}$ to continue awarding high hibah returns and subsidising future pilgrims.

After May 2018, a recovery plan was immediately initiated to restore TH's financial position. This involved forming an aptly named special purpose vehicle company (SPV), Urusharta Jamaah Sdn Bhd, ${ }^{5}$ to take over TH's impaired assets. Additionally, TH reviewed its assets allocation with a renewed focus on reducing high-risk components in favour of lower risk fixed income components. As of 31 December 2018, TH completed the transfer of its underperforming assets (worth RM19.9 billion) to the SPV. The SPV issued RM10 billion of seven-year sukuk and RM9.9 billion of Islamic redeemable convertible preference shares (RCPS-i) in exchange for the assets. The asset transfer did not involve cash transactions or government guarantees on the sukuk. The sukuk were fully subscribed by TH, redeemable at any time without penalty, and carried a yield of 5 per cent. As of 30 September 2019, TH has cleaned up its financial position, with higher assets than liabilities to the tune of RM2.3 billion. Over the same period, TH also recorded RM2.1 billion in income and a net profit of RM1.3 billion. Additionally, TH has been placed under Bank Negara Malaysia's (BNM) supervision since 1 January 2019 to restore depositor trust. Previously, BNM did not have any regulatory oversight over TH, as the fund was solely governed by the Tabung Haji Act 1995.

These restructuring exercises impacted TH in two ways. First, it made it difficult for TH to maintain high hibah payments as in previous years. Prior to 2019, savings made at TH used a wadiah yad-dhamanah (deposits with guarantee) contract. One of the most significant implications of this contract was that the deposits made at TH were considered a 'loan'. Therefore, there should not have been any explicit mention of a return, as this would constitute riba' (interest). ${ }^{6}$ Thus, by virtue of the contract, TH actually had complete discretion over any profit and was obligated to pay back deposits only. Profit distribution, known as hibah, was not legally contracted or compulsory as in conventional savings accounts. In December 2019, as part of its restructuring plan, TH announced a contract change from wadiah yad dhamanah to wakalah, in which the depositor (muwakkil) appointed TH as their representative (wakil) to handle their affairs. From the depositors' point of view, there was no significant difference between the two contracts as the government of Malaysia still guaranteed deposits as per the 
Tabung Haji Act 1995. ${ }^{7}$ Under this new wakalah contract, however, deposits are treated as capital that TH will invest as it sees fit. Any return, minus management fees, hajj costs, and zakat payments, will then be disbursed to depositors. According to the Chairman of TH's Shariah Advisory Committee, Ashraf Md. Hashim, one of the most significant implications of this change is the instilling of responsibility and discipline among the $\mathrm{TH}$ management team. It fosters a culture of transparency when managing deposits. Apart from that, operationally it will be easier for TH to tie deposits to gifts, which was prohibited under the previous contract. The new contract also creates a proviso that a small portion of the return on deposits will be used to cover hajj-related costs and expenses. ${ }^{8}$

The second impact of restructuring $\mathrm{TH}$ has been difficulty maintaining subsidy payments for hajj costs. TH currently subsidises a high amount of hajj cost, considering this to be its primary corporate social responsibility (CSR). Depositors have enjoyed a massive amount of subsidy for a very long time, ever since TH's inception. This 'tradition' has led to depositors almost expecting a hajj subsidy, as if they had forgotten Allah's command that hajj is compulsory only on those who have the financial and physical means to complete it. In any case, TH currently carries a high financial obligation that might jeopardise its sustainability; a series of news reports consequently asked whether $\mathrm{TH}$ would reduce or even cancel it subsidy for hajj costs. ${ }^{9}$ The public has roundly criticised this news, being under the illusion that hajj subsidy is their right. What has followed is an unprecedented criticism of $\mathrm{TH}$, especially on social media platforms, so much so that a campaign to withdraw savings ensued. This muchpublicised 'outcry' finally resulted in TH announcing its subsidy continuation: the amount to be borne by pilgrims remains RM9,980, despite ever-increasing hajj costs. ${ }^{10}$ Undoubtedly, this will further increase TH's financial commitment, which is currently undergoing restructuring, at a time when priority should be given to restoring financial stability.

As the first hajj savings institution of its kind, TH has generated a vast body of literature. Regardless, it is surprising to see how few studies have focused on TH's subsidy structure, which is often mentioned only superficially. One notable gap in the literature concerns the extent to which TH's structure is inherently flawed and unsustainable. Accordingly, this paper aims to review the literature on hajj, revisit the concept of subsidy in Islam, and then suggest a way forward for TH. The paper is divided into six sections. The first two describe the issues surrounding the current subsidy structure and how it is no longer sustainable. Then comes a literature review covering hajj, $\mathrm{TH}$, and the Islamic economic perspective on subsidies. The authors' views on subsidies and their effects on sustainability conclude the paper. 


\section{Literature Review}

\section{Hajj in Islam}

Hajj is one of the five pillars of Islam. It is the pilgrimage to Mecca in Saudi Arabia, which occurs during the final month of the Islamic calendar, dzulhijjah. The commandment to perform hajj stems from the following ayat:

In it are clear signs [such as] the standing place of Abraham. And whoever enters it shall be safe. And [due] to Allah from the people is a pilgrimage to the House - for whoever is able to find thereto a way. But whoever disbelieves - then indeed, Allah is free from need of the worlds. (Al-Imran: 97)

Hajj demonstrates the submission of Muslims to Allah. It is mandatory for Muslims who are financially and physically capable (istitha' $a$ h) to complete this pilgrimage at least once in their lifetime. The Office of the Mufti of the Federal Territory lists several guidelines defining financial capability, including (among other things) the ability to cover all expenses (two-way travel, wage of hajj/ umrah guide) and the possession of surplus savings (after the deduction of debt and family expenses).

\section{An Overview of Lembaga Tabung Haji}

The incorporation of TH was suggested in 1959 by the well-known Malaysian rural economist, the late Ungku Aziz Ungku Abdul Hamid. The idea was mooted in his Rancangan Membaiki Ekonomi Bakal-Bakal Haji ('Pilgrims Economy Improvement Plan'), in which he suggested that the Federal Government establish a financial institution to help Muslim Malays save money for hajj. A prevailing problem at that time, which Ungku particularly wanted to address, was that most (if not all) pilgrims used to sell their assets (land, houses, farms) to fund their pilgrimage. Hence, they had to start afresh upon their return. Consequently, Perbadanan Wang Simpanan Bakal-Bakal Haji (PWSBH, 'Malayan Muslim Pilgrims Saving Corporation') was established on 1 April 1963. On 8 August 1969, PWSBH was merged with Pejabat Urusan Tabung Haji ('Hajj Affairs Management Office'), which had been in operation since 1951 in Penang. The two together were rebranded Lembaga Urusan Tabung Haji (LUTH) and, finally, Lembaga Tabung Haji. Fundamentally, TH's incorporation enabled Muslims to save for hajj through shariah-compliant investments. ${ }^{11}$

TH's establishment received an incredible response from Malaysian Muslims, as evidenced by the subsequent annual growth in depositors: from only 1,281 depositors in 1963, as of 31 December 2018, 9.3 million Malaysians have savings 
with TH. From an initial government grant of RM152,000 in 1963, total deposits in TH reached about RM71 billion as of 30 June 2019. ${ }^{12}$ For the past five years, the average year-on-year growth rate in TH depositors has been 3 per cent, with an increase in total deposits of RM54.35 billion in 2014 to more than RM70 billion in 2018 (Table 1). But, even though the number of depositers has been increasing, it should be noted that TH has recently experienced a reduction in growth, from 18 per cent (2014) to 8.5 per cent (2017).

\begin{tabular}{|c|c|c|c|c|c|}
\hline Items & $\mathbf{2 0 1 4}$ & $\mathbf{2 0 1 5}$ & $\mathbf{2 0 1 6}$ & $\mathbf{2 0 1 7}$ & $\mathbf{2 0 1 8}$ \\
\hline Deposits & $\begin{array}{c}\text { RM54,358 } \\
\text { million }\end{array}$ & $\begin{array}{c}\text { RM62,548 } \\
\text { million }\end{array}$ & $\begin{array}{c}\text { RM67,704 } \\
\text { million }\end{array}$ & $\begin{array}{c}\text { RM73,522 } \\
\text { million }\end{array}$ & $\begin{array}{c}\text { RM75,412 } \\
\text { million }\end{array}$ \\
\hline $\begin{array}{c}\text { Deposit } \\
\text { Growth }\end{array}$ & $19 \%$ & $15 \%$ & $8.2 \%$ & $8.6 \%$ & $2.6 \%$ \\
\hline $\begin{array}{c}\text { No. of } \\
\text { Depositors }\end{array}$ & 8.6 million & 8.8 million & 9.1 million & 9.3 million & 9.21 million \\
\hline
\end{tabular}

Table 1: Depositors Record (Source: TH Annual Reports) ${ }^{13}$

Before its restructuring in 2018, TH recorded an excellent financial performance (Table 2), which led to high hibah payments: the highest rate was made during the financial year ending 31 December 2017, with saw a hibah rate of 4.5 per cent and a hajj hibah rate of 1.75 per cent. According to TH's latest financial information (30 September 2019), however, there has been a significant reduction in revenue from RM4.57 billion to RM2.10 billion, with a corresponding decrease in net profit from RM3.4 billion in 2017 to RM1.3 billion in 2019. Despite this significant reduction, it should be noted that the number of depositors still increased to 9.4 million in 2019, as compared to 9.3 million in 2017 (Table 1). Nevertheless, we still need to consider the recent restructuring exercises that have resulted in a net asset reduction from RM69 billion in 2017 to RM2.3 billion in 2019. This will lead to lower profits shared among higher numbers of depositors.

\begin{tabular}{|c|c|c|c|c|c|c|}
\hline Items & $\begin{array}{c}\mathbf{2 0 1 4} \\
\text { (RM } \\
\text { Million) }\end{array}$ & $\begin{array}{c}\mathbf{2 0 1 5} \\
\mathbf{( R M} \\
\text { Million) }\end{array}$ & $\begin{array}{c}\mathbf{2 0 1 6} \\
\mathbf{( R M} \\
\text { Million) }\end{array}$ & $\begin{array}{c}\mathbf{2 0 1 7} \\
\text { (RM } \\
\text { Million) }\end{array}$ & $\begin{array}{c}\mathbf{2 0 1 8} \\
\text { (RM } \\
\text { Million) }\end{array}$ & $\begin{array}{c}\mathbf{2 0 1 9} \\
\text { (RM } \\
\text { Million) }\end{array}$ \\
\hline Revenue & 3,289 & 4,467 & 3,481 & 4,572 & 4,229 & 2,100 \\
\hline Net Profit & 2,979 & 3,536 & 2,486 & 3,412 & 1,600 & 1,300 \\
\hline Net Assets & 54,006 & 59,462 & 63,573 & 69,380 & 75,769 & 74,000 \\
\hline
\end{tabular}

Table 2: Summary of TH's Financial Performance (Source: TH Annual Reports) ${ }^{14}$ 


\section{Subsidy in Islam}

According to de Moor and Calamai (1997), a subsidy is a direct or indirect provision that reduces consumer or producer costs in order to maintain prices either below (for consumers) or above (for producers) market levels. ${ }^{15}$ From the Islamic economic point of view, a subsidy is permissible as a wealth redistribution mechanism. One of the Rightly Guided Caliphs, 'Umar alKhattab, made a remarkable effort to this end. After the conquest of Iraq (14AH), 'Umar decided to improve the Muslim community's economic growth and welfare; whereas conquered lands had formerly been divided among soldiers (who had no consistent salary) so they could provide for their families, seeing much unemployment also existed among old peasants, 'Umar determined it would be in the public's best interest to leave arable lands with their owners and impose a kharaj (land tax) instead. The Qur'anic verse 'Umar relied upon here was: ${ }^{16}$

And what Allah restored to His Messenger from the people of the towns - it is for Allah and for the Messenger and for [his] near relatives and orphans and the needy and the [stranded] traveler- so that it will not be a perpetual distribution among the rich from among you. And whatever the Messenger has given you - take; and what he has forbidden you - refrain from. And fear Allah; indeed, Allah is severe in penalty. (Al-Hashr: 7)

Muhammad Umer Chapra has argued that Muslim government subsidies should consider the welfare of the poor above everything else. Therefore, any decision to hand out subsidies to poor TH depositors can easily be defended, either with regard to equity and/or economic considerations. But, Obaidullah and Islahi (2003) argue, hajj is an Islamic obligation only for those who can afford it. ${ }^{17}$ Thus, it is morally wrong for Muslims to demand hajj subsidies. These authors then further emphasise the importance of distinguishing between a hajj institution and pilgrims. First and foremost, a hajj institution is not a pilgrim's representative. It is merely a body that provides hajj management and services. In lieu of this, the institution is supposed to price packages prudently. Ultimately, the pilgrims are the ones responsible for their financial capability to perform hajj.

\section{Hajj Subsidies in Other Countries}

Hajj management differs markedly from one country to another. Before 2014, hajj management in the world's most populous Muslim majority country, Indonesia, was managed solely by its government. In that year, however, the Indonesian government issued Law No. 34/2014, obliging the formation of a hajj fund 
management agency, Badan Pengelola Keuangan Haji (BPKH). As an independent public legal entity, BPKH is accountable to the President through the Minister of Religious Affairs and officially began operation in 2018. With its establishment, Muslims can place deposits under a wakalah contract with the Ministry of Religious Affairs as their wakil. ${ }^{18}$ Subsequently, returns from the deposits and any investments will be used to subsidise hajj costs, cover operational expenses, and provide any returns to the accounts of pilgrims. ${ }^{19}$ The actual cost of performing pilgrimage is around IDR60-70 million per person; the subsidy currently paid by BPKH covers approximately 35 per cent of this total cost. ${ }^{20}$

In India, hajj management is arranged by the Hajj Committee, as per the Hajj Committee Act 1959. The hajj fund is held in trust and remains under the control and management of the Committee. While the Indian government has subsidised hajj costs since 1954, this has not been without criticism, even among Muslims themselves. In their view, it is improper to use taxpayer's money for religiousoriented purposes without a referendum. According to Maulana Mehmood Madani, the general secretary of Jamiat Ulema-e-Hind ('Council of Indian Muslim Scholars'), it is against the shariah "to be under any kind of obligation while undertaking hajj." ${ }^{21}$ Additionally, according to Kamal Faruqui, a member of the All India Muslim Personal Law Board, hajj subsidies have been used as a "political tool" for decades. ${ }^{22}$ Among the issues that ultimately led to the abolition of Indian hajj subsidies, however, was the allegation that subsidy payments were being channeled to the national carrier, Air India, as the only carrier that can take pilgrims to Saudi Arabia. According to Mukhtar Abbas Naqvi, India's Minister for Minority Affairs, scrapping the subsidy is part of "a policy to empower minorities with dignity and without appeasement." Although the hajj subsidy programme had its origins in the British colonial era, the Indian Constitution does not allow the state to show favouritism to any religious group. Consequently, in 2012, the Supreme Court opined that the subsidy should be abolished within ten years (by 2022). ${ }^{23}$ In its place, a hajj subsidy fund would be installed for the educational empowerment of girls and women from minority communities.

Previously, the Pakistani government also managed hajj under its Ministry of Religious Affairs and Interfaith Harmony. The government provided a subsidy for hajj costs (Rs42,000 per pilgrim), but in 2019 there was a hike in costs due to several factors, including increased airfares, depreciation of the Pakistani rupee, and additional logistical arrangements in Medina and Mecca. Furthermore, the Saudi government began imposing an additional fee of SR300 on visas and SR110 on compulsory health insurance. These significant increases in the hajj cost further burdened the Pakistani government's expenditure, resulting in the abolition of the hajj subsidy in 2019. This has reduced the cost burden to the government, amounting to Rs4.5 billion per year. 
Those of Malaysia's immediate neighbours with sizeable Muslim populations, such as Singapore and Brunei, do not subsidise their pilgrims.

\section{Discussion: Subsidy and the Sustainability of TH}

Performing hajj is a significant financial commitment, involving substantial expenditure, including on return flights, onsite transportation, accommodation, meals, and visa payments. ${ }^{24} \mathrm{TH}$ has continuously subsidised both these and other indirect costs, such as the production of hajj guidebooks and brochures, hajj courses, hajj officers (welfare and medical), cost for hajj operations in Malaysia, medicines, and various value-added services provided to all Malaysian pilgrims. ${ }^{25}$ To further compound the problem, the actual hajj cost per pilgrim keeps increasing, mainly due to inflation (see Figure 1). ${ }^{26}$

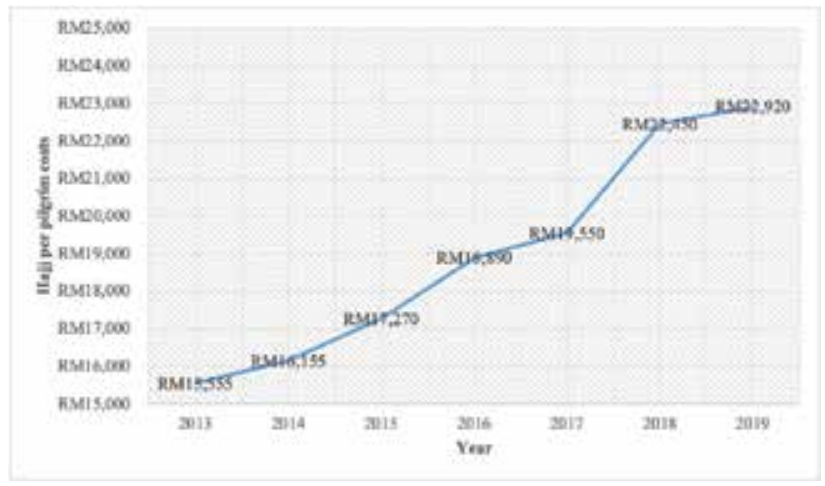

Figure 1: Hajj per pilgrim costs in Malaysia (2013-2019)

As of 2019, the total cost for the hajj stands at RM22,920.00 per person. To put this in context, the middle 40 per cent (M40) of Malaysian Muslim households have a median income of RM7,093, meaning they would have to save up at least 3.2 months salary, in full and without deduction, in order to perform hajj. This situation is even more challenging for the bottom 40 per cent (B40), who only earn up to RM3,166 per month, meaning they have to save eight months' salary. Moreover, as highlighted by the Credit Counselling and Management Agency (AKPK), ${ }^{27}$ saving habits among Malaysians are far from ideal: three out of ten working adults have to borrow to buy necessities. As a result, it is especially difficult for low and middle income households to save for pilgrimage. Therefore, it makes sense for the government to step in and top up wherever possible.

Certainly, TH has been heavily subsidising first-time pilgrims, including those accompanying them, in order to maintain their hajj payments at RM9,980. This has been especially true over the last couple of years (2018 and 2019), when 
subsidies reached more than half the total hajj cost (55.55 per cent and 56.46 per cent, respectively). This subsidy has increased in line with increases in the country's hajj quota. For example, before the hajj cancellation announcement in June 2020, it was announced that Malaysia would receive an additional quota of 31,600 pilgrims, all of whom would need to be subsidised. ${ }^{28}$ Furthermore, TH spent RM576.38 million over 2014-2018 on 58,118 pilgrims who appealed. ${ }^{29}$ During the 2019 hajj season, TH was forced to find RM400 million in subsidies. ${ }^{30}$ Worryingly, the subsidy amount for 2019 alone almost equaled the combined amount for the last five years.

As explained above, while India and Pakistan formerly subsidised their pilgrims, they have since abolished such schemes. In those two countries, the subsidy was funded directly by the government. In Malaysia, however, the subsidy is funded by TH and its business activities. Given the ever-rising cost of hajj and TH's current financial position, this is no longer sustainable. As with any other financial restructuring exercise, the main point of TH's restructuring is to ensure continued sustainability. In all, TH's restructuring is expected to continue for at least the next seven years, consistent with the maturity period of the sukuk issued by Urusharta Jamaah Sdn Bhd. Thus, continued subsidies vis-à-vis the current financial situation seem to burden TH. Hence, while waiting for the sukuk to mature, the main concern is how to finance the two most significant financial components of TH: hibah and its hajj subsidy.

To do this, we need to revisit the concept of istitha'ah (capability). This concept is typically associated with a pilgrim's physical capability to perform the rigorous hajj rituals. Undoubtedly, however, financial capability is just as crucial. Such a redefinition of istitha'ah echoes the call by former Minister in the Prime Minister's Department (Religious Affairs), Mujahid Yusuf Rawa, that, "If he/she does not have sufficient cost of performing hajj in 2019, which is RM22,900, then he/she should not be considered as financially capable [of performing hajj]." ${ }^{31}$

If the main objective of a subsidy is to ensure equitable distribution of income, the current subsidy practiced by $\mathrm{TH}$ defeats that purpose. The subsidy is also taking away essential resources needed by $\mathrm{TH}$ for its sukuk coupon payments. Also, the monies used for hajj subsidy could be used elsewhere, such as for financial literacy programmes (as in India).

\section{The Way Forward}

Concerning subsidies, Umer Chapra argues that, "Only those who are unable to pay a realistic price should be helped." 32 Stated differently, TH should only help those who cannot afford either the full payment or a near-to-full payment of hajj costs. While, ideally, a government will prefer to give out as little as possible, 
eliminating TH subsidies altogether is absurd; anything related to $\mathrm{TH}$ or, by extension, Islam is a sensitive and touchy issue in Malaysia. This is evidenced by the sudden withdrawal of the TH deposit in 2017, when depositors were hugely dissatisfied with the scandal TH faced. But, continuing the current trajectory of blanket subsidies covering more than half the full pilgrimage cost (56.46 per cent as of 2019) is equally absurd, especially when TH is undergoing restructuring.

While the authors believe that a sudden and blanket withdrawal of hajj subsidies in Malaysia is impossible because depositors (regardless of household income) are deeply invested in $\mathrm{TH}$, the continuation of blanket subsidies without a viable exit plan is unworkable. From experience, it is safe to assume hajj costs will only continue to rise. Therefore, without subsidies most low-income households will probably be priced out of the hajj. According to Mahatma Gandhi, "How a society treats its most vulnerable is always the measure of its humanity." Hence, the well-to-do part of society needs to step up and do their part in paying their full (or near full) hajj costs in order to help their brethren in line with the spirit of ta'awun (cooperation). Ultimately, this redistributive scheme will foster goodwill within society, in which the well-off help marginalised households.

Therefore, as a way forward, the authors believe the TH subsidy structure should be targeted. It could, for example, tap into the Inland Revenue Board (LHDN) database to determine the exact household income of future pilgrims. TH could then practice a targeted, regressive subsidy structure. For instance, according to household income brackets, subsidies could be broken down as follows: 20 per cent subsidy for T20; 40 per cent for M40; and 60 per cent for B40. ${ }^{33}$ Consider the following mathematical example:

\begin{tabular}{|c|c|c|c|}
\hline Household Group $^{34}$ & Rate of Subsidies & TH Subsidies & ${\text { Costs payable to } \text { TH }^{35}}^{35}$ \\
\hline Top $20 \%$ (T20) & $20 \%$ & RM4,584 & RM18,336 \\
\hline Middle $40 \%$ (M40) & $40 \%$ & RM9,168 & RM13,752 \\
\hline Bottom $40 \%$ (B40) & $60 \%$ & RM13,752 & RM9,168 \\
\hline
\end{tabular}

Table 3: Proposed subsidy structure

If the subsidy structure were more targeted, TH management could fulfill its CSR practices sustainably. In fact, at RM9,168, the B40 would pay less than under the current system. More importantly, the new subsidy structure complies with shariah and, to a certain extent, with maqasid al-shari'ah (objectives of Islamic law). This exercise would re-allocate much-needed subsidies to the parts of society that need them most. Having said this, it should be noted that the proposed revision would also result in additional administration costs, as it involves screening and evaluating depositor financial standing. However, this is 
acceptable as it will ensure TH's long-term sustainability. Besides, if the subsidy is regressively structured, $\mathrm{TH}$ will have the capability to adjust it.

\section{Conclusion}

This paper discussed the unsustainability of TH's existing subsidy structure. Coupled with the restructuring exercises that $\mathrm{TH}$ is currently undergoing, this structure must be overhauled. Drawing upon the experience of other Muslim majority countries, it is absurd to think a business entity can continue this subsidy practice. This paper suggested a targeted, regressive subsidy structure as a way forward. In the meantime, we propose the following actionable policy recommendations:

- Promote better financial literacy. There are at least three dimensions to this point. First, TH and, to a certain extent, the government should highlight that subsidies are not a right. They are a privilege. Second, it is crucial to educate the public, particularly depositors, about the implications of TH's contract change from wadiah yad dhamanah to wakalah. This change has been undertaken for the sake of safeguarding investments; it is nevertheless essential to inform depositors that hibah and subsidy payments are affected by it. Depositors must also be aware that TH's performance will be based on cycles of boom and bust, as with any business. This will be reflected in its returns: an economic boom will mean a high subsidy, an economic recession a low subsidy. Third, it is time to introduce a new subject into Islamic finance: hajj education. Like other aspects of Islamic financial education, such as takaful, zakat, hibah, wasiyyah, and waqf, there is a need to teach hajj financial management in order to avoid misconceptions.

- Create a shariah ruling for TH's hajj subsidy. In line with the changes in TH's contract, it is recommended that the authorities issue a shariah ruling (fatwa) on the hajj subsidy. This can be achieved through a special sitting of the National Council for Malaysian Islamic Affairs Fatwa Committee. Although their decision is not binding on $\mathrm{TH}$, it will carry considerable clout among Malaysian Muslims. This is important to rectify Muslim perceptions about their responsibility to perform hajj and not put unnecessary burden or expectations on TH. This will also highlight the importance of istitha' $a h$. As a reference point, the experiences of India and Pakistan may also guide the Committee's fatwa regarding the hajj subsidy - or rather, the redirection of hajj subsidies to those who need them most. 
On a concluding note, this proposed structure is a somewhat short-to-middle term solution. As the above mentioned financial literacy programmes start to mature, however, we may begin to practice the concept of istitha' $a h$ in its purest form so that only pilgrims with the physical and financial means to perform hajj do so.

\section{Notes}

* Nur Hasnida Abdul Rahman is an Assistant Professor at the Department of Finance, Kulliyyah of Economics and Management Sciences, International Islamic University Malaysia. She has 15 years of working experience in the banking industry, particularly in business banking operations. Her specialisation is SMEs and infrastructure financing, mainly covering business banking development, structuring financing products, credit evaluation, credit administration, credit supervision, and credit recovery. Email: nhasnida@ iium.edu.my.

** Mohd Zaidi Md Zabri is a Senior Lecturer at the Department of Finance and Banking, Faculty of Business and Accountancy, University of Malaya. He is the corresponding author and can be contacted at: zaidizabri@um.edu.my.

1. Hajj is a five-day religious pilgrimage to Mecca, in modern-day Saudi Arabia. It is one of the five pillars of Islam and, therefore, required of every Muslim who is physically and financially able to perform it.

2. Rahimy Rahim, 'Dr M: Tabung Haji Plays Effective Role in Ensuring Welfare of Haj Pilgrims,'The Star, 4 August 2019.

3. On 16 September 1963, six years after the Federation of Malaya's independence from the British, Malaya, Sabah, Sarawak, and Singapore formed a federal state called Malaysia. However, on 9 August 1965, due to political and economic differences, Singapore separated from Malaysia.

4. Hajj hibah is reserved only for those depositors yet to perform hajj.

5. In Malay, Urus Harta Jamaah loosely translates as 'Managing the Pilgrim's Assets'.

6. Any increase, addition, unjust return, or advantage obtained by a lender as a condition of their loan is considered riba'. Besides riba', the other two fundamental prohibitions in Islamic finance are maysir (gambling) and gharar (uncertainty).

7. BERNAMA, 'Wakalah: Pengurusan Deposit Lebih Efisien,' Sinar Harian, 2019. Available at: https://www.sinarharian.com.my/article/61873/BERITA/Nasional/ Wakalah-Pengurusan-deposit-lebih-efisien.

8. Endang Jumali, 'Management of Hajj Funds in Indonesia,' Journal of Legal, Ethical and Regulatory Issues 21, no. 3 (2018): 1-9.

9. Muhammed Ahmad Hamdan, 'Subsidy for first-time pilgrims, except B40s, to be removed next year?' The Edge Financial Daily, 2020. Available at: https:// www.theedgemarkets.com/article/subsidy-firsttime-pilgrims-except-b40s- 
beremoved-next-year.

10. BERNAMA, 'Haj Subsidy remains for first-time Haj pilgrims: Mujahid,' New Straits Times, 2019. Available at: https://www.nst.com.my/news/ nation/2019/02/464625/haj-subsidy-remains-first-time-haj-pilgrims-mujahid.

11. Aishath Muneeza, Amira Sudeen, Atiqoh Nasution, and Ratih Nurmalasari. 'A Comparative Study of Hajj Fund Management Institutions in Malaysia, Indonesia and Maldives,' International Journal of Management and Applied Research 5, no. 3 (2018): 120-34; Ali and Ghani, Mohammad Mahbubi Ali and Nur Amalina Abdul Ghani, 'Tabung Haji: Public Concern and Future Direction,' Islam and Civilisational Renewal 10, no. 1 (2019): 132-35.11.

12. BERNAMA, 'Tabung Haji posts higher profit in 1H,' New Straits Times, 2019. Available at: https://www.nst.com.my/business/2019/07/507186/tabung-hajiposts-higher-profit-1h.

13. The annual report for 2019 has yet to be published due to the ongoing auditing process. Once audited, the report needs to be tabled and approved by the Cabinet. Subsequently, the report needs to be tabled in Parliament before being made public.

14. The figures for FY2014 through FY2018 can be obtained from TH's Annual Reports. The figures for FY2019 were obtained from 'Tabung Haji Report Card 2019.'

15. André de Moorde Moor and Peter Calamai, 'Subsidizing Unsustainable Development: Undermining the Earth with Public Funds,' The Hague: Institute for Research on Public Expenditure, 1997. Available at: https://grist.org/wpcontent/uploads/2010/04/cs-incearthcouncil-unsustainable-en.pdf.

16. Muhammad Yousuf Faruqi, 'Modes of Ijtihad in the Judgements of the Khulafa Al-Rashidun,' Intellectual Discourse 1, no. 1 (1993): 9-27.

17. Mohammed Obaidullah and Abdul Azim Islahi, 'Financial and Shariah Analysis of Hajj-Related Services: A Case Study,' The Muslim World League Journal 31, no. 1 (2003): 22-27.

18. Jumali, 'Management of Hajj Funds in Indonesia.'

19. Yosi Winosa, 'Independent Agency to Manage Indonesia's $\$ 6.7$ Bln Hajj Fund to Start in Q4,' Salaam Gateway, 2017. Available at: https://www.salaamgateway. com/en/story/independent agency to_manage_indonesias_6.7_bln_hajj_fund to_start_in_q4-SALAAM2̄6022017̄080529.

20. Muneeza et al., 'A Comparative Study of Hajj Fund Management Institutions in Malaysia, Indonesia and Maldives.'

21. Zakir Hussain, Saudi Arabia in a Multipolar World: Changing Dynamics (London: Routledge, 2016), 223.

22. Zeenat Saberin, 'India Ends Government Subsidies for Hajj Pilgrimage,' Aljazeera, 2018. Available at: https://www.aljazeera.com/news/2018/01/16/ india-ends-governmentsubsidies-for-hajj-pilgrimage/?gb=true.

23. Ibid.

24. Tabung Haji, 'Haji Costs and Payment.'

25. It is important to note that these subsidies only apply to those who have yet to perform hajj.

26. The latest hajj season (2020) was a scaled back affair restricted to only 10,000 pilgrims (both Saudi nationals and expatriates) already resident in Saudi Arabia. 
A normal hajj season, on the other hand, will host around 2.5 million pilgrims from around the world.

27. AKPK is an agency set up by Bank Negara Malaysia to help Malaysians better manage their finances.

28. The hajj quota is given to 0.01 per cent of a country's population based on the United Nation's World Population Prospect statistics. Stated differently, the quota is set at 1,000 pilgrims per one million Muslims. However, as populations grow, so too will this sample size. Customarily, in Malaysia almost every year the Minister in the Prime Minister's Department (Religious Affairs) appeals for an increase in hajj quota due to population increases.

29. BERNAMA, 'Tabung Haji Spent RM576.4 Million on Subsidies for 58,118 Pilgrims in Last 5 Years,' New Straits Times, 2019. Available at: https://www. nst.com.my/news/nation/2019/04/477666/tabung-haji-spent-rm5764-millionsubsidies-58118-pilgrims-last-5-years.

30. Hamdan, 'Subsidy for first-time pilgrims, except B40s, to be removed next year?'

31. Siti Nursyahidah Abu Bakar, 'Haji Perlu Dilakukan Dengan Kemampuan,' Sinar Harian, 2019. Available at: https://www.sinarharian.com.my/article/19112/ BERITA/Nasional/Haji-perlu-dilakukan-dengan-kemampuan.

32. M. Umer Chapra, Islam and the Economic Challenge (Leicester: The Islamic Foundation, 1992), 292 (emphasis added).

33. This proposed subsidy structure was developed using the baseline of the current subsidy percentage (2019 hajj season), which stood at 56.46 per cent.

34. These median household incomes are based on the Household Income and Basic Amenities Survey 2019 conducted by the Department of Statistics Malaysia (DOSM), which defined the median incomes of the B40, M40, and T20 households as RM3,166, RM7,093, and RM15,021 respectively.

35. At the cost price of RM22,920 (as of 2019 hajj season).

\section{Bibliography}

Abu Bakar, Siti Nursyahidah. 'Haji Perlu Dilakukan Dengan Kemampuan.' Sinar Harian, 2019. Available at: https://www.sinarharian.com.my/article/19112/ BERITA/Nasional/Haji-perlu-dilakukan-dengan-kemampuan.

Ali, Mohammad Mahbubi, and Nur Amalina Abdul Ghani. 'Tabung Haji: Public Concern and Future Direction.' Islam and Civilisational Renewal 10, no. 1 (2019): 132-35.

BERNAMA. 'Haj Subsidy Remains for First-Time Haj Pilgrims: Mujahid.' New Straits Times, 2019. Available at: https://www.nst.com.my/news/nation/2019/02/464625/ haj-subsidy-remains-first-time-haj-pilgrims-mujahid.

. 'Tabung Haji Posts Higher Profit in 1H.' New Straits Times, 2019. Available at: https://www.nst.com.my/business/2019/07/507186/tabung-haji-posts-higherprofit-1h.

'Tabung Haji Spent RM576.4 Million on Subsidies for 58,118 Pilgrims in Last 5 Years.' New Straits Times, 2019. Available at: https://www.nst.com.my/ 
news/nation/2019/04/477666/tabung-haji-spent-rm5764-million-subsidies58118-pilgrims-last-5-years.

'Wakalah: Pengurusan Deposit Lebih Efisien.' Sinar Harian, 2019. Available at: https://www.sinarharian.com.my/article/61873/BERITA/Nasional/WakalahPengurusan-deposit-lebih-efisien.

Chapra, M. Umer. Islam and the Economic Challenge. Leicester: The Islamic Foundation, 1992.

Faruqi, Muhammad Yousuf. 'Modes of Ijtihad in the Judgements of the Khulafa AlRashidun.' Intellectual Discourse 1, no. 1 (1993): 9-27.

Hamdan, Muhammed Ahmad. 'Subsidy for First-Time Pilgrims, except B40s, to Be Removed next Year?' The Edge Financial Daily, 2020. Available at: https://www. theedgemarkets.com/article/subsidy-firsttime-pilgrims-except-b40s-be-removednext-year.

Hussain, Zakir. Saudi Arabia in a Multipolar World: Changing Dynamics. London: Routledge, 2016.

Jumali, Endang. 'Management of Hajj Funds in Indonesia.' Journal of Legal, Ethical and Regulatory Issues 21, no. 3 (2018): 1-9.

Moor, André de, and Peter Calamai. 'Subsidizing Unsustainable Development: Undermining the Earth with Public Funds.' The Hague: Institute for Research on Public Expenditure, 1997. Available at: https://grist.org/wp-content/ uploads/2010/04/cs-inc-earthcouncil-unsustainable-en.pdf.

Muneeza, Aishath, Amira Sudeen, Atiqoh Nasution, and Ratih Nurmalasari. 'A Comparative Study of Hajj Fund Management Institutions in Malaysia, Indonesia and Maldives.' International Journal of Management and Applied Research 5, no. 3 (2018): 120-134.

Obaidullah, Mohammed, and Abdul Azim Islahi. 'Financial and Shariah Analysis of Hajj-Related Services: A Case Study.' The Muslim World League Journal 31, no. 1 (2003): 22-27.

Rahim, Rahimy. 'Dr M: Tabung Haji Plays Effective Role in Ensuring Welfare of Haj Pilgrims.' The Star, 2019. Available at: https://www.thestar.com.my/news/ nation/2019/08/04/dr-m-tabung-haji-plays-effective-role-in-ensuring-welfare-ofhaj-pilgrims.

Saberin, Zeenat. 'India Ends Government Subsidies for Hajj Pilgrimage.' Aljazeera, 2018. Available at: https://www.aljazeera.com/news/2018/01/16/india-endsgovernment-subsidies-for-hajj-pilgrimage/?gb=true.

Tabung Haji. 'Hajj Cost \& Payment,' 2020. Available at: https://www.tabunghaji.gov. my/index.php/en/hajj/hajj-cost-payment.

Winosa, Yosi. 'Independent Agency to Manage Indonesia's \$6.7 Bln Hajj Fund to Start in Q4.' Salaam Gateway, 2017. Available at: https://www.salaamgateway. com/en/story/independent_agency_to_manage_indonesias_6.7_bln_hajj_fund to_start_in_q4-SALAAM26022017080529. 